\title{
Study on Information Service Push Strategy based on Networked Manufacture
}

\author{
Feng Xiu-zhen, Su Chao \\ School of Economics and Management \\ Beijing University of Technology \\ Beijing, China \\ e-mail: xfeng@bjut.edu.cn, suchao1818@163.com
}

\begin{abstract}
Based on exploring the characteristics of networked manufacture, we first analyzed the relationships on the networked manufacture. Then, we constructed architecture of information push service for networked manufacture, which is based on the detailed discussion with the related data structure. Furthermore, we proposed two information push strategies correspondingly to deal with different types of products, such as existing products and new products. Finally, push strategies were verified with an empirical study for the efficiency and effectiveness.
\end{abstract}

Keywords-networked manufacture; information push; push strategy; similarity study

\section{INTRODUCTION}

Networked Manufacture is an advanced manufacturing mode that is based on computer technology, network communication technology and manufacture technology, which could be conducted as trans-territory or trans-regional manufacturing. Taking advantage of internet technology, networked manufacture business can be benefit from manufacture resource sharing, operational cost reducing, and fast responding to the market demand.

Information service and information management are one of the research hotspots in the networked manufacture research field, such as networked manufacture information service platform analysis and design ${ }^{1,2}$ research on collaborative interactive technology of networked manufacture platform ${ }^{3}$ and etc. In this paper we first explored the characteristics of relationships between supply and demand for the networked manufacture enterprises. Then, the architecture of networked manufacture information push service was constructed. Based on the discussions on the relevant data structure, the information push strategies were proposed. Finally, we verified the efficiency and effectiveness of information push strategies with an empirical study.

\section{DEMAND-SUPPLY RELATIONSHIPS FOR NETWORKED MANUFACTURE ENTERPRISES}

Networked manufacture environment is comprised of many manufacture enterprises based on their demand-supply relationships. As a matter of fact, each enterprise is an important node in the network. On one hand, networked manufacture enterprises play the role of suppliers that provide various manufacture resources to the downstream enterprises. On the other hand, networked manufacture enterprises also play the role of demanders that demand necessary manufacture resources from upstream enterprises. In this way, the supply-demand relationships among enterprises in networked manufacture environment are multilayered. Moreover, the supply-demand relationships can be changed or reconnected as manufacture demand changed or production technology updated, which is the driving force to keep networked manufacture promoting and developing.

\section{ARCHETECTURE OF NETWORKED MANUFACTURE INFORMATION SERVICE PUSH SYSTEM}

Networked manufacture information generally refers to the related internal and external information of networked manufacture enterprises, including enterprise information, products information, components information and supplier information etc. To be convenient for studying, networked manufacture information can be abstracted as product related information in this paper.

As shown in Figure 1, the architecture of networked manufacture information service push system consist of four layers, such as information resource layer, information service operational layer, enterprise layer and product component layer.

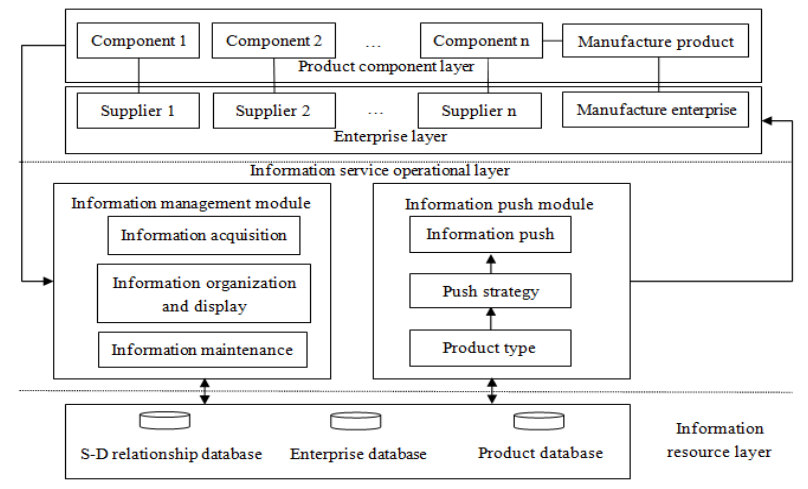

Figure 1. Architecture of Networked Manufacture Information Service Push System.

Information resource layer includes information about supply-demand relationship, enterprise, product and etc. Information about enterprise's supply-demand relationship covered relevant cooperation among the networked manufacture enterprise. Enterprise information includes networked manufacture enterprise's cooperation characteristics. Product information reflected product's characteristics. Information service operational layer has 
two modules, such as information management module and information push module. The fundamental functions of information management module are information acquisition, organization, display and maintenance. The function of information push module is used to look for proper suppliers of components for networked manufacture enterprises. Enterprise layer includes relevant networked manufacture enterprises. Product component layer includes manufactured products and the required components.

\section{NETWORKED MANUFACTURE INFORMATION PUSH STRATEGY}

\section{A. Data Structure of Networked Manufacture Information Push}

\section{1) Data Structure of Networked Manufacture} Enterprise

PPCM= (MR, OP, EN, CCT, ICTR, EAPTA), this formula is used to represent the cooperation characteristic information of networked manufacture enterprise. In the formula, MR - operating revenue from main business, OPoutput, EN-number of practitioner. We use three factors to specify the enterprise's scale, such as CCT-turnover rate of current capital, ICTR - tax rate of industrial capital, and EAPTA - employee's average profit and tax amount.

2) Data Structure of Networked Manufacture Product Information

$\mathrm{P}=(\mathrm{PN}, \mathrm{PAS}, \mathrm{PPS})$, this formula is used to represent information about product. In the formula, $\mathrm{PN}$ - product number, which can identify one product from others; PASproduct's feature set that can be specified as $\mathrm{PAS}=\left(\mathrm{PA}_{1}, \mathrm{PA}_{2}, \ldots, \mathrm{PA}_{\mathrm{m}}\right)$. This formula is used to list product's characteristic information. PPS-product's component set, which is $\mathrm{PPS}=\left(\mathrm{PN}_{1}, \mathrm{PN}_{2}, \ldots, \mathrm{PN}_{\mathrm{n}}\right)$.

\section{B. Networked Manufacture information Service Push Strategy}

We proposed two kinds of information push strategies: one is to select supplier based on product, and the other is to push product information to the networked manufacture enterprises with the related demands. In fact, networked manufacture enterprises may have existing products as well as new products. As to existing products, information push service should focus on potential suppliers, which will provide more opportunities to select proper suppliers for networked manufacture enterprise. Besides, it can search for the networked manufacture enterprises with product demand, and send the related product information to the downstream networked manufacture enterprises. For the new product, the focus of information push service is to choose proper component suppliers based on product information and the cooperation characteristics related enterprises, and push the suppliers' information to the related manufacture enterprises, as well as find out the enterprises with potential demand.

1) Existing Product Information Push Strategy

a) Component Supplier Information Push Strategy

Based on the characteristic information of component from networked manufacture enterprise, we can search for the enterprises that are more similar to existing supplier of component.

The detailed steps are shown as follows:

- $\quad$ Find the existing suppliers according to component characteristic information, and get the enterprise' supplier set ESS. By the same token, find all enterprises that supply the component in the networked manufacture in the same way, and get the enterprise set SS;

- Going through the enterprises in ESS, we could start from enterprise ESS1, be based on its cooperation characteristic information, standardize characteristics with formula (1) and calculate ESS1'S similarity to enterprises in SS with formula (2), set the threshold value as $\theta$, and the collection of the enterprises whose $\operatorname{sim} \geq \theta$ is the set of the enterprises similar to ESS1---PESS1;

$$
\begin{gathered}
\mathrm{b}_{\mathrm{ip}}=\mathrm{a}_{\mathrm{ip}} / \max \left(\mathrm{a}_{\mathrm{ip}}\right) \\
\operatorname{sim}(\mathrm{x}, \mathrm{y})=\cos (\mathrm{x}, \mathrm{y})=\sum_{\mathrm{i}=1}^{\mathrm{n}} \mathrm{x}_{\mathrm{i}} \mathrm{y}_{\mathrm{i}} / \sqrt{\sum_{\mathrm{i}=1}^{\mathrm{n}} \mathrm{x}_{\mathrm{i}}^{2} \sum_{\mathrm{i}=1}^{\mathrm{n}} \mathrm{y}_{\mathrm{i}}^{2}}
\end{gathered}
$$

- $\quad$ Repeat the previous step until all enterprises in ESS have been processed, and finally get the set of potential suppliers for the component required by the enterprise (PESS), and PESS = UPESSi-ESS .

b) Information Push Strategy for Enterprise with Demand on Product

As the cooperation relationship of enterprise's existing product demand reflects the actual product demand among networked manufacture enterprises, at this point, the target of information push service is to find out enterprises with the potential product demand from networked manufacture enterprises according to the features of existing product demand.

Detailed description can be presented as following:

- Based on product characteristic information, find out the enterprises with existing demand related with the product of the enterprise, and get the set of enterprises with product demand EDS. Then get all enterprises related with the demand on the product in manufacture industry, and define the enterprise set DS;

- Going through EDS, we start from enterprise EDS1 based on its cooperation characteristic information, and standardize characteristics with formula (1), then to calculate EDS1's similarity to all enterprises in DS with formula (2), set the threshold value as $\theta$, and the collection of the enterprises whose $\operatorname{sim} \geq \theta$ is the set of the enterprises similar to EDS1---PEDS1;

- Repeat the previous step until all enterprises in EDS have been processed, then get the set of the enterprises with potential demand on the product $(\mathrm{PEDS})$, and PEDS $=\mathrm{U}$ PEDSi- EDS . 


\section{2) New Product Information Push Strategy}

a) Component Supplier Information Push Strategy

Information push service could find out component suppliers according to component information and the related enterprises' cooperation characteristic information.

Detailed Description can be listed as following:

- Based on component characteristic information and networked manufacture enterprise's type, find out all of the enterprises related with this component, and get the enterprise set TE;

- According to enterprise's cooperation characteristic information, standardize characteristics with formula (1) and then calculate the networked manufacture enterprise's similarity to all of the enterprises in TE with formula (2), set the threshold value as $\theta$, namely, the collection of enterprises whose $\operatorname{sim} \geq \theta$ is the set of enterprises similar to the networked manufacture enterprise ---SES;

- Find out the suppliers that provide the component for the enterprises in SES, and get the set of potential suppliers for the component required by the networked manufacture enterprise PESS.

b) Enterprise Information Push Strategy for Enterprises with Product Demand

The information push strategy works in this way: based on new product's characteristic information, and find out the products related networked manufacture enterprises that will have potential demand on the product.

Detailed Description can be showed as following:

- According to product characteristic information, find out the products with similar functions, and form the product set $\mathrm{PNS}=\{\mathrm{PN} 1, \mathrm{PN} 2, \ldots, \mathrm{PNi}\}$;

- Taking the product PN1 for the example, we can find out the enterprises with the demand of the product in manufacture industry, and get the enterprise set PEDS1;

- Repeat the previous step until all products in PNS have been processed, and get the set of the enterprises with the potential demand on the product PEDS, and PEDS $=$ UPEDSi .

\section{EMPIRICAL STUDIES}

\section{A. Cooperation Network of Automobile Manufacture Industry}

Taking Yearbook of Automobile Industry 2011 and portals of networked manufacture enterprises as information source, we selected automobile sealing-parts manufacture enterprises and related car manufacture enterprises to construct the supply-demand network, if the sealing-parts output volumes exceed RMB 100 million. Their relationship can be depicted in Figure 2. In the figure 2, represents the sealing-parts manufacture enterprises. represents the automobile manufacture enterprises cooperated with the sealing-parts manufacture enterprise.

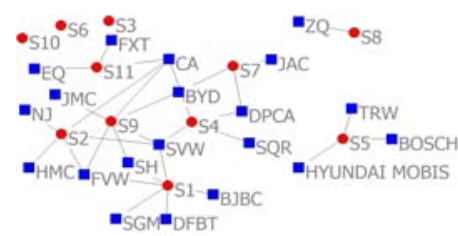

Figure 2. S-D Cooperation Network Diagram.

\section{B. Empirical Analysis}

\section{1) Existing Product Information Push Strategy}

a) Component Supplier Information Push Strategy

TABLE I listed the related sealing-parts suppliers' cooperation characteristic information.

TABLE I. TABLE ON THE RELATED SEALING-PARTS SUPPLIERS' COOPERATION CHARACTERISTIC INFORMATION

\begin{tabular}{|c|c|c|c|c|c|c|}
\hline $\begin{array}{c}\text { Sealing-Parts } \\
\text { Suppliers }\end{array}$ & P & WAPTA & CTN & PTIC & EN & SR \\
\hline S1 & 75250 & 114000 & 2.57 & 16.38 & 766 & 90662 \\
\hline S2 & 59507 & 38628 & 1.44 & 13.07 & 7240 & 228897 \\
\hline S3 & 42269 & 155327 & 2.4 & 52.87 & 903 & 43487 \\
\hline S4 & 38422 & 35290 & 2.65 & 13.54 & 1023 & 37530 \\
\hline S5 & 21833 & 61983 & 2.17 & 41.32 & 1200 & 21726 \\
\hline S6 & 19240 & 62247 & 1.7 & 11.16 & 260 & 19985 \\
\hline S7 & 18311 & 46415 & 1.94 & 19.24 & 1481 & 50662 \\
\hline S8 & 17350 & 60742 & 1.19 & 24.47 & 436 & 10353 \\
\hline S9 & 15480 & 50260 & 0.23 & 1.68 & 375 & 25574 \\
\hline S10 & 14878 & 80152 & 2 & 10.42 & 132 & 14494 \\
\hline S11 & 10200 & 45059 & 1.2 & 19.82 & 340 & 21765 \\
\hline
\end{tabular}

TABLE II. SEALING PART'S CHARACTERISTIC INFORMATION

\begin{tabular}{|c|c|c|c|}
\hline $\begin{array}{c}\text { Internal } \\
\text { diameter(mm) }\end{array}$ & $\begin{array}{c}\text { External } \\
\text { diameter(mm) }\end{array}$ & $\begin{array}{c}\text { Thickness } \\
(\mathbf{m m})\end{array}$ & $\begin{array}{c}\text { Temperature } \\
\left({ }^{\circ} \mathrm{C}\right)\end{array}$ \\
\hline 1.7 & 2.7 & 2 & 300 \\
\hline
\end{tabular}

We assume that component characteristic information of the sealing parts demanded by BYD is shown in TABLE II. The push strategy can be conducted. And the relevant results can summarize as TABLE III. We could get the potential cooperation network that can be shown in Figure 3.

TABLE III. BYD SUPPLIER INFORMAITON PUSH RELEVANT RESULTS

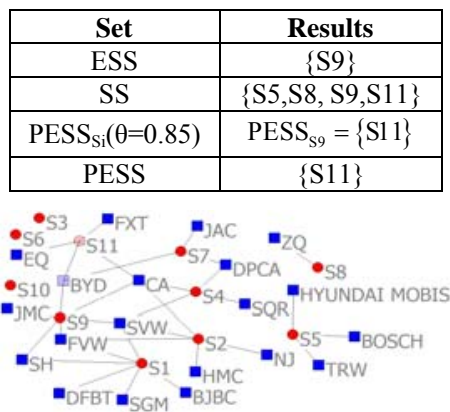

Figure 3. BYD S-D Potential Cooperation Network Diagram.

b) Information Push Strategy for Enterprises with Product Demand

TABLE IV listed the related automobile manufacture enterprises' cooperation characteristic information. 
TABLE IV. TABLE ON The Related Automobile MANufacture ENTERPRISES' COOPERATION CHARACTERISTIC INFORMATION

\begin{tabular}{|c|c|c|c|c|c|c|}
\hline $\begin{array}{c}\text { Automobile } \\
\text { Manufacture } \\
\text { Enterprises }\end{array}$ & P & WAPTA & CTN & PTIC & EN & SR \\
\hline FVW & 882827 & 3132364 & 3.61 & 78.33 & 15477 & 13145020 \\
\hline SVW & 1017249 & 1291736 & 4.76 & 65.74 & 18753 & 12469853 \\
\hline SGM & 513180 & 3935974 & 4.19 & 69.23 & 7159 & 13159319 \\
\hline BJBC & 39740 & 736396 & 4.19 & 69.23 & 5071 & 1676079 \\
\hline HMC & 136022 & 189305 & 2.71 & 17.86 & 3739 & 776010 \\
\hline SQR & 691924 & 93375 & 2.32 & 7.76 & 22448 & 3537922 \\
\hline JAC & 464061 & 153312 & 4.38 & 20.17 & 16798 & 2972136 \\
\hline JMC & 188856 & 377713 & 1.8 & 54.59 & 9653 & 1576790 \\
\hline EQ & 673838 & 12229413 & 1.81 & 41.31 & 10000 & 8175052 \\
\hline CA & 264573 & 164631 & 3 & 15.84 & 21105 & 5360393 \\
\hline BYD & 521232 & 78057 & 4.14 & 29.63 & 183317 & 2143840 \\
\hline ZQ & 214890 & 121587 & 1.72 & 5.74 & 27302 & 8119180 \\
\hline Selectin & S & & &
\end{tabular}

Selecting S8 that produces existing sealing parts (as shown in TABLE II), the relevant results can be presented as shown in TABLE V. And we get the potential cooperation network, as shown in Figure 4.

TABLE V.

S8 DEMANDER INFORMATION PUSH RELEVANT RESULTS

\begin{tabular}{|c|c|}
\hline Set & Results \\
\hline EDQ & $\{$ ZQ $\}$ \\
\hline DS & $\{$ SVM,SGM,JMC,ZQ $\}$ \\
\hline PEDS $=$ PEDS \\
\hline
\end{tabular}

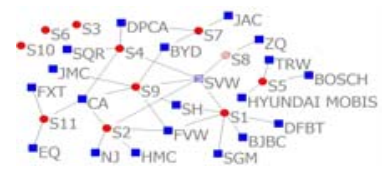

Figure 4. S8 S-D Potential Cooperation Network Diagram.

2) New Product Information Push Strategy

a) Component Supplier Information Push Strategy

TABLE VI. NE SEALING PART'S CHARACTERISTIC INFORMATION

\begin{tabular}{|c|c|c|c|}
\hline $\begin{array}{c}\text { Internal } \\
\text { diameter(mm) }\end{array}$ & $\begin{array}{c}\text { External } \\
\text { diameter(mm) }\end{array}$ & $\begin{array}{c}\text { Thickness } \\
\mathbf{( m m})\end{array}$ & $\begin{array}{c}\text { Temperature } \\
\left({ }^{\circ} \mathrm{C}\right)\end{array}$ \\
\hline 1.7 & 2.7 & 2.5 & 300 \\
\hline
\end{tabular}

Assuming enterprise CA now plans to produce a car and needs the sealing parts as shown in TABLE VI, the relevant results can be presented as shown in TABLE VII. And get the potential cooperation network, as shown in Figure 5.

TABLE VII. NE SUPPLIER INFORMAITON PUSH RELEVANT RESULTS

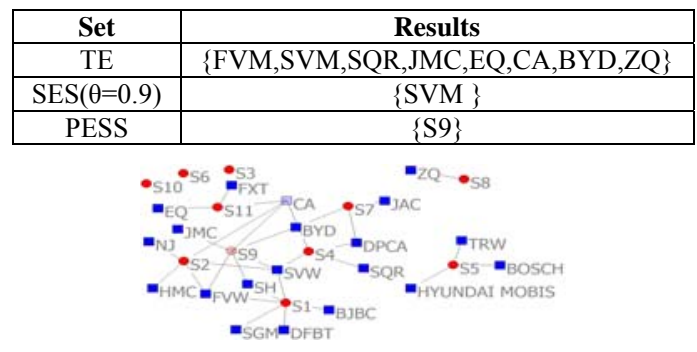

Figure 5. NE S-D Potential Cooperation Network Diagram. b) Enterprise Information Push Strategy for Enterprises with Product Demand

TABLE VIII. S8 SEALING PART's CHARACTERISTIC INFORMATION

\begin{tabular}{|c|c|c|c|}
\hline $\begin{array}{c}\text { Internal } \\
\text { diameter(mm) }\end{array}$ & $\begin{array}{c}\text { External } \\
\text { diameter(mm) }\end{array}$ & $\begin{array}{c}\text { Thickness } \\
\mathbf{( m m})\end{array}$ & $\begin{array}{c}\text { Temperature } \\
\left({ }^{\circ} \mathrm{C}\right)\end{array}$ \\
\hline 1.7 & 2.7 & 2 & 400 \\
\hline
\end{tabular}

As for enterprise S8, it produces new sealing part (as shown in TABLE VIII), the push strategy is implemented. We get the relevant results as shown in TABLE IX. And we get the potential cooperation network, as shown in Figure 6.

TABLE IX. S8 DEMANDER INFORMATION PUSH RELEVANT RESULTS

\begin{tabular}{|c|c|}
\hline Set & Results \\
\hline PNS & $\{\mathrm{PN} 1, \mathrm{PN} 2, \mathrm{PN} 4\}$ \\
\hline $\mathrm{PEDS}_{\mathrm{PN}}$ & $\mathrm{PEDS}_{\mathrm{PN} 1}=\{\mathrm{SGM}, \mathrm{BYD}\} ; \mathrm{EDS}_{\mathrm{PN} 2}=\{\mathrm{FVM}\} ; \mathrm{PEDS}_{\mathrm{PN} 4}=\{\mathrm{SGM}\}$ \\
\hline PEDS & $\{\mathrm{FVM}, \mathrm{SGM}, \mathrm{BYD}\}$ \\
\hline
\end{tabular}

Figure 6. S8 S-D Potential Cooperation Network Diagram.

\section{CONCLUSIONS}

According to exploring the supply-demand relationships among networked manufacture enterprises, we proposed two information push strategies correspondingly to deal with different types of products. Push strategies could help networked manufacture enterprises quickly and accurately establish a new cooperation network based on the original cooperation relationship, and provide highly efficient information service for enterprises.

\section{ACKNOWLEDGMENT}

The work was supported by Beijing Planning Office of Philosophical and Social Science "Eleventh Five-Project" Fund (10AbJG389).

\section{REFERENCES}

[1] Maria Leonilde R. Varela, Rui Barbosa, and Goran D. Putnik, "Experimental platform for collaborative inter and intra cellular fuzzy scheduling in an ubiquitous manufacturing system", Communications in Computer and Information Science, vol. 248, 2012, pp. 220-229, doi: 10.1007/978-3-642-31800-9_23.

[2] Yao Tao and Zhang Yimin, "Coordinated Design and Manufacturing Information Management Platform of Mechanical Products". Mechanical Management and Development, No.6, Dec.2012, pp. 183187, doi: 1003-773X (2012) 06-0183-04.

[3] Kim Jong Hwan, Joung Youn-kyoung, and Noh Sang Do, "Product information exchanges between CAD/PDM systems and the collaboration portal system using PLM services", 2009 WRI World Congress on Computer Science and Information Engineering, 2009, pp. 718-721, doi: 10.1109/CSIE.2009.962. 